Сучасні двигуни зможуть бути двопаливними, працювати на СПГ та водороді.

Використання водороду, як палива на морському флоті відповідають всім вимогам безпеки мореплавання. Проте для виконання повністю всіх вимог по запобіганню забруднення довкілля необхідне виробництво «зеленого» водороду.

\title{
Література:
}

1. Шауэнберг Т., Позднякова Н. Рекорд по выбросам CO2: эксперты ООН о реальной угрозе человечеству, 2019. URL: https://p.dw.com/p/3TkAh (дата звернення: 23.09.2020).

2. The world's largest-class hydrogen production, Fukushima Hydrogen Energy Research Field (FH2R) now is completed at Namie town in Fukushima, 2020. URL:https://ecotechnica.com.ua/energy/4749krupnejshij-zavod-po-proizvodstvu-zelenogo-vodoroda-otkryt-vfukusime.html (дата звернення: 23.09.2020).

DOI https://doi.org/10.30525/978-9934-588-79-2-1.44

\section{ВПЛИВ ЗМІННОГО СТУПЕНЯ СТИСНЕННЯ НА ПОКАЗНИКИ РОБОТИ ДВЗ}

\author{
Хоменко В. С. \\ викладач кафедри суднового машинобудування та енергетики \\ Херсонської філії Національного університету кораблебудування \\ імені адмірала Макарова \\ Савчук П. С. \\ студент \\ Херсонської філії Національного університету кораблебудування \\ імені адмірала Макарова \\ м. Херсон, Украӥна
}

В останні роки спостерігається значний прогрес у підвищенні паливної економічності і зниження вмісту токсичних компонентів у відпрацьованих газах автомобільних та суднових двигунів. Провідні двигунобудівні фірми, беручи участь в безперервній гонці за екологічними нормами і борючись за споживача, змушені вдосконалювати 
двигуни, використовуючи найновіші конструктивні та технологічні рішення.

До останнього часу вважалося аксіомою, що ступінь стиснення $є$ незмінним конструктивним параметром двигуна, таким як, наприклад, діаметр циліндра. Дійсно, в традиційних двигунах величина ступеня стиску однозначно визначається розмірами кривошипно-шатунного механізму, висотою поршня, а також розташуванням головки циліндра відносно осі колінчастого валу.

Як відомо, потужність і паливна економічність двигуна зростають при збільшенні ступеня стиснення внаслідок підвищення індикаторного ККД. При досягненні величин ступеня стиснення $13 \ldots 14$ поліпшення показників двигуна припиняється через неминуче зростання механічних втрат. Тому зазначені величини ступеня стиснення $є$ оптимальними [1].

У той же час закладена в конструкцію двигунів величина ступеня стиснення відрізняється від оптимальної. У бензинових двигунах ступінь стиснення обмежується детонацією. Вона менше оптимальної i, як правило, не перевищує 10. У дизелях ступінь стиснення вибирається 3 урахуванням забезпечення надійного самозаймання палива при пуску холодного двигуна. Вона більше оптимальної і для дизелів 3 безпосереднім уприскуванням палива рідко опускається нижче 16, а для вихрокамерних дизелів доходить до 24.

Численні розрахунки і експериментальні дослідження показали, що і для бензинового двигуна і для дизеля регулювання ступеня стиснення здатне забезпечити приблизно однакове поліпшення паливної економічності на 20\%, хоча причини цього і алгоритм регулювання ступеня стиснення для бензинового двигуна і для дизеля різні [2].

У дизелі з регулюванням ступеня стиснення можна значно збільшити тиск наддуву, підвищивши за рахунок цього потужність. А можна зберігши попередню потужність знизити робочий об'єм (кількість циліндрів), поліпшивши при цьому паливну економічність, зменшивши масу і вартість двигуна.

Кількість запропонованих конструкцій, що дозволяють регулювати ступінь стиснення і робочий об'єм двигуна дуже великий. Однак, переважна більшість 3 них, теоретично дозволяючи вирішувати поставлені завдання по управлінню рухом поршнів, виявилися не придатними для практичної реалізації через неможливість забезпечити прийнятну працездатність двигуна, або з технологічних причин.

При автоматичному регулюванні процесу стиснення без підвищення максимального тиску циклу може бути забезпечено наступне [3]: 
1) істотне підвищення питомої потужності в результаті реалізації більш високих тисків наддування при збереженні економічності на неномінальних режимах;

2) розширення області допустимих режимів роботи внаслідок реалізації великих тисків наддування;

3) поліпшення паливної економічності, особливо форсованих по наддуванню дизелів;

4) зниження теплової напруженості деталей камери згорання в результаті використання на режимі номінальної потужності більшого значення $\varepsilon$;

5) розширення діапазону вживаних палив;

6) поліпшення пускових якостей при негативних температурах довкілля;

7) зниження токсичності відпрацьованих газів;

8) підвищення ефективності роботи ДВЗ при змінних параметрах довкілля.

До загальних недоліків двигунів 3 регульованим процесом стиснення слід віднести деяке ускладнення конструкції окремих вузлів або додавання нових.

Розглянемо вплив підвищення ступеня стиснення на показники роботи двигунів. Термічний ККД двигуна $\eta_{\mathrm{t}}$ значною мірою залежить від величини ступеня стиснення є. Чим вище ступень стиснення, тим менше палива використовується для отримання тієї ж самої потужності. Тому підвищення ступеня стискання - один з основних методів збільшення потужності двигуна. Термічний ККД двигуна при збільшенні $\varepsilon$ збільшується спочатку швидко, а після $\varepsilon=12 \ldots 13$ - дещо повільніше.

При збільшенні тривалості такту впускання за допомогою установки розподільного валу з тривалішим періодом впускання приріст потужності від ступеню стискання стає ще значнішим [4].

Однак, збільшення ступеня стиску не завжди призводить до збільшення потужності. Якщо статично (підрахована) ступінь стиску вже знаходиться біля межі детонації для використовуваного палива, іiі подальше збільшення може погіршити потужність або надійність двигуна. Це особливо справедливо, коли досягнутий коефіцієнт наповнення циліндра більше 1. До того ж, коли коефіцієнт наповнення циліндра більше 1 , суміш, що поступила, знаходиться під невеликим позитивним тиском, проте, вона може заповнити тільки простір в циліндрі враховуючи простір в камері згорання. Проте якщо ми збільшуємо ступінь стиснення шляхом зменшення об'єму камери згорання або шляхом збільшення опуклості поршня, то загальна кількість 
паливоповітряної суміші, яка може бути заключна в даному об'ємі, зменшиться на цю величину, i, як наслідок, при збільшенні ступеня стиснення погіршується наповнення циліндрів. Чим краще наповнення циліндрів (отримане зміною фаз газорозподілу і т.п.), тим менше буде необхідний ступінь стиснення.

Вплив ступеня стиснення на ефективні показники роботи суднових ДВ3 досліджується за допомогою моделювання робочого циклу. Розрахунок проводиться зі значними припущеннями і виконаний за методом Гриневецького-Мазінга .

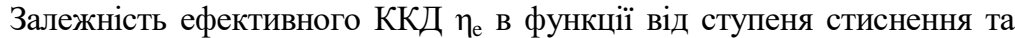
повітропаливного співвідношення розраховується по відомій формулі [5]:

$$
\eta_{\mathrm{e}}=\varphi_{0} \cdot\left(\eta_{\mathrm{t}}-0,024 \cdot \alpha \cdot(\varepsilon+8,5) \cdot\left(1-\eta_{\mathrm{m}}\right)\right)
$$

де $\varphi_{0}-$ коефіцієнт втрати теплоти, враховуючий округлення індикаторної діаграми;

$\eta_{\mathrm{m}}$ - механічний ККД дизеля;

$\eta_{\mathrm{t}}$ - термічний ККД циклу, розрахований з урахуванням теплопередачі і залежності теплоємності робочого тіла від складу газу і температури.

Нижче наведена залежність термічного ККД $\eta_{t}$ (рис. 1) та ефективного ККД $\eta_{\mathrm{e}}$ (рис. 2) від ступеня стиснення $\varepsilon$ на основі формули (1) для двигуна 6Ч18/22.

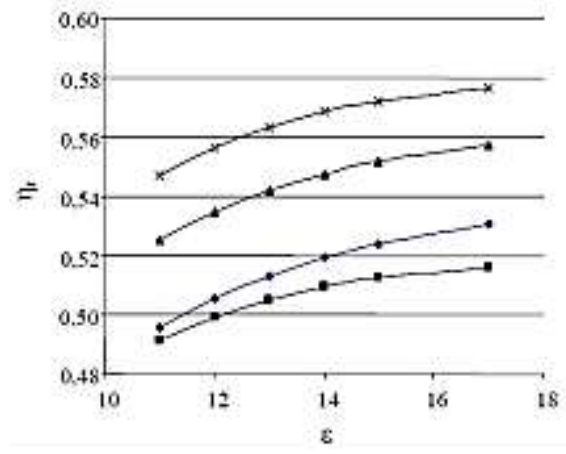

Рис. 1. Графік залежності $\eta_{t}$ від зміни $\varepsilon$ Режим роботи дизеля, \% від $\mathbf{N}_{\text {ном }}$

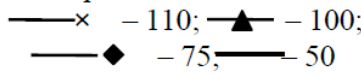




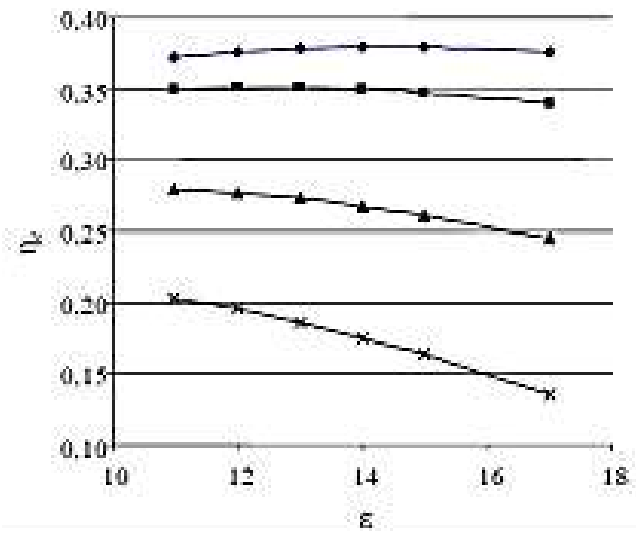

Рис. 2. Графік залежності $\eta_{\mathrm{e}}$ від зміни $\varepsilon$ Режим роботи дизеля, \% від $\mathbf{N}_{\text {ном }}$

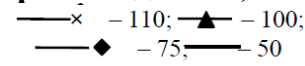

Висновки.

1. Збільшення потужності двигуна при збільшенні стиснення можливо в межах підвищення ефективності двигуна.

2. Регулювання ступеня стиснення на часткових навантаженнях забезпечує ефективну роботу двигуна на більш бідних сумішах. Так, підвищення ступеня стиснення в діапазоні від 7 до 12,5 призводить до збільшення коефіцієнта надлишку повітря.

3. У зв'язку з переважним зростанням механічних втрат на ефективну продуктивність в кривошипно-шатунному механізмі існує оптимальне значення $\varepsilon_{\text {opt }}$ в кожному перехідному режимі, вище якого збільшувати коефіціснт стиснення недоцільно.

\section{Література:}

1. Тер-Мкртичьян Г.Г. Двигатели внутреннего сгорания с нетрадиционными рабочими циклами: учеб. пособие / Г.Г. Тер-Мкртичьян. М. : МАДИ. 2015. - 80 с.

2. Тырловой С.П. Разработка поршней 4-х тактного дизеля с регулируемой степенью сжатия и анализ его динамических качеств: диссертация на соискание ученой степени кандидата технических наук / Тырловой Сергей Иванович. Ворошиловград. 1984. - 254 с.

3. Хуциев А.И. Двигатели внутреннего сгорания с регулируемым процессом сжатия / Хуциев А.И. - М.: Машиностроение. 1986. -104 с. 
4. Шароглазов Б. А. Двигатели внутреннего сгорания: теория, моделирование и расчёт процессов : учебник по курсу «Теория рабочих процессов и моде-лирование процессов в двигателях внутреннего сгорания» / Б. А. Шароглазов, М. Ф. Фарафонтов, В. В. Клементьев Челябинск : Изд. ЮУрГУ, 2004. - 344 с.

5. Наливайко, В.С. Суднові двигуни внутрішнього згоряння : підруч. для студентів ВНЗ / В. С. Наливайко, Б. Г. Тимошевський, С. Г. Ткаченко. - Миколаїв : Торубара В. В. [вид.], 2015. - 331 с. 